http://dx.doi.org/10.18778/1509-877X.2018.02.06

\title{
MECHANIZM PODZIELONEJ PŁATNOŚCI - OCENA NOWEJ REGULACJI
}

Streszczenie. Celem artykułu jest ocena przepisów dotyczących mechanizmu podzielonej płatności. W pierwszej kolejności omówiono istotę i modele tego mechanizmu. Następnie wskazano na regulacje $\mathrm{w}$ tym zakresie obowiązujące $\mathrm{w}$ innych państwach. Analizie zostały poddane także przepisy wprowadzające split payment w Polsce. Na koniec zwrócono uwagę na korzyści i zagrożenia związane z mechanizmem podzielonej płatności.

Słowa kluczowe: mechanizm podzielonej płatności, podatek od towarów i usług, oszustwa podatkowe, uszczelnienie systemu podatkowego

1. WPROWADZENIE

Niniejszy artykuł zmierza do oceny przepisów dotyczących mechanizmu podzielonej płatności (ang. split payment). Unormowania te zostały wprowadzone jako odrębny rozdział do Ustawy z dnia 11 marca 2004 r. o podatku od towarów i usług ${ }^{1}$ (dalej: u.p.t.u. lub ustawa).

Zdaniem projektodawców celem omawianego rozwiązania jest zapewnienie większej stabilności wpływów z tytułu podatku od towarów i usług oraz zapobieganie unikaniu płacenia tego podatku. Dzięki temu ma być

* Doktor nauk prawnych, adiunkt w Katedrze Prawa Podatkowego na Wydziale Prawa i Administracji Uniwersytetu Łódzkiego, współpracownik Centrum Dokumentacji i Studiów Podatkowych oraz Fundacji CDiSP, doradca podatkowy, radca prawny, Tax Supervisor w KPMG w Polsce, e-mail: aneta.nowak@wpia.uni.lodz.pl

1 Tekst jedn. Dz.U. z 2018 r., poz. 2174 ze zm. 
zagwarantowane większe bezpieczeństwo podatkowe, pewność prowadzenia działalności gospodarczej oraz zachowanie równych zasad konkurencji.

Niewątpliwie, mechanizm podzielonej płatności służy zapobieganiu uchylaniu się od opodatkowania w zakresie rozliczeń podatku od towarów i usług. Jak podkreślono w Informacji o wynikach kontroli Najwyższej Izby Kontroli (NIK), to właśnie na gruncie tego podatku zidentyfikowano największe ryzyko wystąpienia nieprawidłowości². Problem strat spowodowanych oszustwami w podatku od towarów i usług, jak podkreśla NIK, narastał w ostatnich latach. Jak jednak zauważono, uchylanie się od opodatkowania na gruncie omawianego podatku występuje w całej Unii Europejskiej (UE). Problem ten prowadzi do powstawania ubytków w dochodach budżetowych państw członkowskich ${ }^{3}$. Niemniej jednak rozmiar luki w podatku od towarów i usług, rozumianej jako różnica pomiędzy dochodami podatkowymi należnymi dla budżetu a dochodami faktycznie uzyskanymi, utrzymywał się w Polsce na poziomie wyższym aniżeli średnia wielkość tego zjawiska w UE. Zdaniem NIK występowanie znacznej luki w tym podatku „świadczy o niewystarczającej efektywności polskiego systemu podatkowego i potrzebie wprowadzenia nowych rozwiązań mających na celu ograniczenie oszustw podatkowych" ". Jednym z rekomendowanych przez NIK rozwiązań było wprowadzenie mechanizmu podzielonej płatności ${ }^{5}$. Mechanizm ten jest również rekomendowany przez Komisję Europejską w Studium wykonalności i alternatywnych metod poprawy oraz uproszczenia poboru VAT6

W ostatnich latach do u.p.t.u. wprowadzono wiele rozwiązań mających na celu zapobieganie oszustwom podatkowym. Można do nich zaliczyć przede wszystkim regulacje dotyczące:

a) mechanizmu odwrotnego obciążenia na niektóre towary w obrocie krajowym;

b) odpowiedzialności solidarnej nabywcy za zaległości podatkowe dostawcy określonych towarów;

${ }^{2}$ NIK, Informacja o wynikach kontroli. Przeciwdziałanie wprowadzaniu do obrotu gospodarczego faktur dokumentujących czynności fikcyjne, nr ewid. 24/2016/P/15/011/ KBF, Warszawa 2016, s. 7.

3 Ibidem.

4 Ibidem, s. 13.

5 Ibidem, s. 14.

6 Study on the feasibility of alternative methods for improving and simplifying the collection of VAT through the means of modern technologies and/or financial intermediaries, Executive summary, 20.09.2010, s. 3, https://ec.europa.eu/taxation_customs/sites/taxation/ files/docs/body/vat-study_summ_en.pdf (dostęp: 4.10.2017). 
c) zmian w zakresie rejestracji podatników;

d) sankcji za nierzetelne rozliczanie podatku.

Jak zauważyła jednak NIK, co zostało potwierdzone w uzasadnieniu do omawianego projektu ustawy, wdrożone dotychczas środki okazują się niewystarczające. W związku z tym w ramach uszczelniania systemu podatku od towarów i usług rząd zdecydował się na wprowadzenie rozwiązania systemowego - mechanizmu podzielonej płatności.

\section{ISTOTA I MODELE MECHANIZMU PODZIELONEJ PŁATNOŚCI}

Mechanizm podzielonej płatności, jak wynika z jego nazwy, zakłada podział przez nabywcę kwoty brutto należnej z tytułu dostawy towarów lub świadczenia usług na dwie części: kwotę netto i podatek od towarów i usług. Wydzielona kwota netto jest transferowana na zasadach ogólnych do sprzedawcy, kwota podatku jest zaś przekazywana na specjalny rachunek bankowy, tzw. rachunek $\operatorname{VAT}^{7}$. Model ten upoważnia organy podatkowe do monitorowania i blokowania środków na tym rachunku, co zapobiega wypływowi należności, które powinny pokrywać zobowiązania podatników z tytułu podatku od towarów i usług. Środki z rachunku VAT mogą być wykorzystywane wyłącznie w celu regulowania podatku na rzecz innego podatnika bądź zobowiązania podatkowego w podatku od towarów i usług. W systemie tym moment poboru podatku de facto przesuwa się więc na chwilę dokonania płatności ${ }^{9}$.

Skutkiem zastosowania tego mechanizmu jest wyłączenie kontroli podatnika nad kwotą podatku od towarów i usług. W konsekwencji zapewnia on otrzymywanie przez organy podatkowe całej kwoty tego podatku i umożliwia kontrolowanie przebiegu płatności między podatnikami ${ }^{10}$.

Mechanizm podzielonej płatności ma zastosowanie do płatności dokonywanych elektronicznie. W praktyce w Polsce znajdzie on zatem zastosowanie do wszystkich płatności przekraczających $15000 \mathrm{zl}$, w związku z wprowadzeniem do ustaw o podatkach dochodowych regulacji wyłączającej z kosztów uzyskania przychodów wydatków przewyższających wskazaną kwotę, jeżeli płatność nie jest dokonywana bez pośrednictwa rachunku

7 Split payment. Raport PwC, 2015, s. 4, https://www.pwc.pl/pl/pdf/split-paymentraport-pwc.pdf (dostęp: 4.10.2017).

8 Study on the feasibility..., s. 6.

9 Split payment..., s. 5.

10 Ibidem. 
płatniczego $^{11}$. Omawiany mechanizm dotyczy transakcji dokonywanych pomiędzy podmiotami profesjonalnymi - podatnikami podatku od towarów i usług - relacji B2B (ang. business to business).

Wyróżnia się dwa podstawowe modele mechanizmu podzielonej płatności: zautomatyzowany i manualny. W pierwszym przypadku następuje automatyczny podział kwoty płatności brutto podczas dokonywania płatności za towar lub usługę. Nabywca dokonuje wówczas jednego polecenia przelewu, płatność dzielona jest zaś na kwotę netto, która trafia do sprzedawcy, i kwotę podatku, przekazywaną na wydzielony rachunek VAT ${ }^{12}$. Model ten może występować w różnych wariantach, tj. przewidujących:

a) zablokowanie konta VAT na poziomie banku podatnika;

b) zablokowanie konta VAT na poziomie automatycznego systemu rozrachunkowego;

c) zablokowanie konta VAT na poziomie banku organu podatkowego ${ }^{13}$.

Pierwszy wariant zakłada funkcjonowanie banku nabywcy jako płatnika podatku (to bank po otrzymaniu dyspozycji przelewu dokonuje rozdzielenia kwoty - na kwotę brutto i kwotę podatku). W drugim systemie wykorzystuje się system rozrachunkowy banku, który działa również jako inkasent podatku (system dokonuje rozdzielenia płatności). W trzecim przypadku natomiast po podziale przez system rozrachunkowy kwoty płatności kwota VAT przekazywana jest na konto VAT sprzedawcy w banku organu podatkowego ${ }^{14}$.

Manualny system płatności z kolei wymaga od nabywcy samodzielnego dokonania dwóch dyspozycji przelewów: na kwotę netto trafiającą do sprzedawcy i kwotę podatku przekazywaną na wyodrębniony rachunek VAT ${ }^{15}$.

Należy podkreślić, że system manualny wymaga poniesienia najmniejszych nakładów pracy i kosztów związanych z jego wdrożeniem. Eliminuje on bowiem konieczność odpowiedniego dostosowania systemów płatności przez banki. Z drugiej jednak strony odpowiedzialność za prawidłowe

11 Artykuł 22p Ustawy z dnia 26 lipca 1991 r. o podatku dochodowym od osób fizycznych (tekst jedn. Dz.U. z 2016 r., poz. 2032 ze zm.) oraz art. 15d Ustawy z dnia 15 lutego 1992 r. o podatku dochodowym od osób prawnych (tekst jedn. Dz.U. z 2016 r., poz. 1888 ze zm.).

12 Split payment..., s. 5.

13 Study on the feasibility..., s. 3.

14 Split payment..., s. 6-7.

15 Ibidem, s. 5. 
podzielenie kwoty płatności spoczywa na podatniku, a zatem dodatkowe koszty implementacji mechanizmu podzielonej płatności mogą zostać przesunięte na przedsiębiorców.

\section{MECHANIZM PODZIELONEJ PŁATNOŚCI W INNYCH PAŃSTWACH}

Polska, wprowadzając analizowane rozwiązanie, jest jednym z prekursorów w tym zakresie w ramach UE. Dotychczas na wprowadzenie tego mechanizmu zdecydowały się Włochy, Rumunia oraz w ograniczonym stopniu Czechy.

\section{Włochy}

We Włoszech mechanizm podzielonej płatności funkcjonuje od 1 stycznia 2015 r. Celem jego wprowadzenia było ograniczenie w tym państwie luki w podatku VAT. Przyjęto manualną wersję split payment. Obowiązek jego stosowania dotyczy dostaw towarów i świadczenia usług na rzecz podmiotów prawa publicznego ${ }^{16}$. Mechanizm ten nie odnosi się do dostaw towarów lub świadczenia usług zwolnionych z VAT oraz dokumentowanych wydaniem biletu lub paragonu. System ten nie znajdzie także zastosowania w tych przypadkach, w których obowiązuje mechanizm odwrotnego obciążenia ${ }^{17}$.

Przyjęty model podzielonej płatności zakłada, że nabywca będący podmiotem prawa publicznego przekazuje dostawcy wyłącznie kwotę netto z tytułu dokonanej dostawy towarów lub świadczenia usług, kwotę VAT przelewa zaś bezpośrednio na rzecz Skarbu Państwa.

Należy wskazać, że Włochy 14 lipca 2015 r. uzyskały decyzję derogacyjną Rady na stosowanie mechanizmu podzielonej płatności ${ }^{18}$. W dniu 7 lutego 2017 r. Włochy wystąpiły o wydłużenie obowiązywania derogacji do końca 2020 r. i rozszerzenie jej zakresu na inne podmioty objęte mechanizmem podzielonej płatności (tj. poza podmiotami prawa publicznego, na spółki kontrolowane przez takie podmioty i spółki notowane na giełdzie

16 S. La Grutta, Split-Payment Mechanism for Public Bodies, „International VAT Monitor” 2015, no. 3/4, s. 94 .

17 Ibidem, s. 95.

18 Decyzja wykonawcza Rady (UE) 2015/1401 z dnia 14 lipca 2015 r. w sprawie upoważnienia Włoch do wprowadzenia szczególnego środka stanowiącego odstępstwo od art. 206 oraz art. 226 dyrektywy 2006/112/WE w sprawie wspólnego systemu podatku od wartości dodanej (Dz.Urz. UE L 217 z 2015 r., s. 7-8). 
papierów wartościowych) ${ }^{19}$. W czerwcu 2016 r. Włochy przedstawiły raport, z którego wynika, że w związku z wprowadzeniem mechanizmu podzielonej płatności wzrosły w tym państwie wpływy z VAT i wzrost ten był większy aniżeli spodziewany na etapie planowania tego rozwiązania ${ }^{20}$.

Stosowny dekret zmieniający przepisy $\mathrm{w}$ omawianym zakresie we Włoszech wszedł w życie 1 lipca 2017 r.

Czechy

Czechy wprowadziły manualny system podzielonej płatności. Ma on charakter fakultatywny - podatnicy nie mają obowiązku jego stosowania. Jest to system alternatywny wobec odpowiedzialności solidarnej nabywcy za VAT niezapłacony przez dostawcę towaru bądź usługi (odpowiedzialność ta podlega wyłączeniu, jeżeli nabywca skorzysta z mechanizmu podzielonej płatności). Model ten ma więc ograniczony zakres zastosowania ${ }^{21}$.

W praktyce zastosowanie tego systemu polega na tym, że nabywca dokonuje podziału kwoty należności. Kwotę netto przekazuje zbywcy, a kwotę podatku przelewa bezpośrednio na rachunek bankowy organu podatkowego właściwego dla siedziby sprzedawcy ${ }^{22}$.

Rumunia

Rumunia jest na etapie wprowadzania mechanizmu podzielonej płatności. Od 1 października 2017 r. mechanizm ten był fakultatywny, z kolei od 1 stycznia 2018 r. stał się obligatoryjny ${ }^{23}$.

System ten zakłada podzielenie należnej zbywcy kwoty na wartość netto i VAT. Kwota VAT podlega przekazaniu na odrębny rachunek bankowy zbywcy. Z rachunku tego można regulować jedynie VAT na rzecz

${ }^{19}$ Italy, European Union - Split payment system - request for extension, News IBFD, 22.02.2017, IBFD Tax Research Platform, https://research.ibfd.org/\#/ (dostęp: 4.10.2017).

${ }_{20}$ Proposal for a Council Implementing Decision authorising the Italian Republic to apply a special measure derogating from Articles 206 and 226 of Directive 2006/112/EC on the common system of value added tax, Brussel 2017, IBFD Tax Research Platform, https://research.ibfd.org/\#/ (dostęp: 4.10.2017).

${ }^{21}$ Split payment..., s. 10.

22 Ibidem.

${ }^{23}$ https:/home.kpmg.com/xx/en/home/insights/2017/08/tnf-romania-vat-splitpayment-mechanism-legislation-is-enacted.html (dostęp: 4.10.2017). 
dostawców oraz na rzecz Skarbu Państwa ${ }^{24}$. Przeniesienie środków z tego rachunku na inny rachunek będzie następować wyłącznie za zgodą organów podatkowych ${ }^{25}$.

\section{Mechanizm podzielonej PŁatności w Polsce}

Wprowadzone do u.p.t.u. przepisy przewidują dobrowolny mechanizm podzielonej płatności (wynika to $\mathrm{z}$ art. 108a ust. 1 u.p.t.u.). Oznacza to, że podatnik będący nabywcą towaru lub usługi będzie mógł zadecydować, czy skorzysta $\mathrm{z}$ tej formy regulowania zobowiązania. Ustawa zakłada, że podatnicy mogą stosować ten mechanizm w sposób wybiórczy, tj. niektóre faktury regulować na zasadzie podzielonej płatności, a niektóre w tradycyjny sposób. Tego typu rozwiązanie wydaje się korzystne z punktu widzenia nabywcy - może on bowiem zadecydować, w jaki sposób regulować płatność w przypadku, gdy po jego stronie pojawi się uzasadnione podejrzenie, że druga strona może nie wywiązać się z obowiązku rozliczenia się z podatku od towarów i usług.

Ustawodawca w art. 108a ust. 2 wskazuje, na czym ma polegać mechanizm podzielonej płatności:

1) zapłata kwoty odpowiadającej całości albo części kwoty podatku wynikającej z otrzymanej faktury jest dokonywana na rachunek VAT;

2) zapłata całości albo części kwoty odpowiadającej wartości sprzedaży netto wynikającej z otrzymanej faktury jest dokonywana na rachunek bankowy albo na rachunek w spółdzielczej kasie oszczędnościowo-kredytowej, dla których jest prowadzony rachunek VAT, albo jest rozliczana w inny sposób.

Regulacja ta odpowiada klasycznemu schematowi działania podzielonej płatności, w której należność dla sprzedawcy podlega rozbiciu na kwotę netto i kwotę podatku od towarów i usług. Ustawodawca zakłada, że płatność ma być dokonywana przy użyciu komunikatu przelewu, przeznaczonego do dokonywania płatności w mechanizmie podzielonej płatności. Ustawa wskazuje na zakres informacji, który musi być zawarty w komunikacie przelewu, nie reguluje natomiast technicznych wymagań

${ }^{24}$ http://www.business-review.eu/news/pwc-romania-introduction-of-new-vat-split-payment-system-will-have-major-impact-on-companies-145524 (dostęp: 4.10.2017).

25 https://www2.deloitte.com/content/dam/Deloitte/ro/Documents/tax/english/ ro-tax-legal-weekly-alert-7-11-aug-2017-en.pdf (dostęp: 4.10.2017). 
komunikatów przelewu. Oznacza to, że stworzenie odpowiedniego systemu rozrachunkowego spoczywa na bankach oraz spółdzielczych kasach oszczędnościowo-kredytowych (SKOK). W tym przypadku mamy do czynienia $\mathrm{z}$ automatycznym wariantem mechanizmu podzielonej płatności.

Należy zaznaczyć, że ustawa przewiduje obowiązek dla banku prowadzenia dla podatników rachunku VAT. Rachunek ten podlega obciążeniu tylko w wyraźnie wskazanych przez ustawodawcę sytuacjach, w ogólności dotyczących zapłaty kwoty podatku od towarów i usług z tytułu nabycia towarów lub usług na rachunek VAT oraz regulacji należności podatkowych w zakresie podatku od towarów i usług.

W pewnych przypadkach u.p.t.u. przewiduje możliwość wystąpienia przez podatnika $\mathrm{z}$ wnioskiem o zgodę na przekazanie środków zgromadzonych na rachunku VAT na inny rachunek bankowy lub rachunek w SKOK. Zgodnie z ustawą podatnik we wniosku będzie określał wysokość środków z rachunku VAT, jaka ma podlegać przekazaniu. Naczelnik urzędu skarbowego w razie pozytywnego ustosunkowania się do wniosku wydaje postanowienie (w terminie 60 dni od dnia otrzymania wniosku). Organ odmawia wydania zgody na przekazanie środków w drodze decyzji:

1) w wysokości odpowiadającej posiadanej przez podatnika zaległości podatkowej w podatku wraz z odsetkami za zwłokę, istniejącej na dzień wydania decyzji;

2) w przypadku gdy zachodzi uzasadniona obawa, że:

a) zobowiązanie podatkowe $\mathrm{z}$ tytułu podatku nie zostanie wykonane, w szczególności gdy podatnik trwale nie uiszcza wymagalnych zobowiązań z tytułu tego podatku lub dokonuje czynności polegających na zbywaniu majątku, które mogą utrudnić lub udaremnić egzekucję, lub

b) wystąpi zaległość podatkowa w podatku lub zostanie ustalone dodatkowe zobowiązanie podatkowe.

O ile przesłanka wskazana w pkt 1 ma charakter zobiektywizowany, o tyle w przesłance z pkt 2 wymienione są okoliczności podlegające każdorazowej subiektywnej ocenie organu podatkowego. Istnieje obawa, że instytucja odmowy w tym zakresie może być nadużywana przez organy podatkowe. Poza tym należy zauważyć, że wprowadzenie przez ustawodawcę 60-dniowego terminu na wydanie postanowienia zatwierdzającego przekazanie środków z rachunku VAT na inny rachunek może negatywnie wpływać na płynność finansową przedsiębiorstw, o czym szerzej będzie mowa w dalszej części opracowania. 
U.p.t.u. przewiduje dla podatników zachęty do korzystania z mechanizmu podzielonej płatności. W ustawie wskazuje się bowiem, że do wysokości kwoty podatku odpowiadającej kwocie podatku wynikającej z otrzymanej faktury zapłaconej z zastosowaniem mechanizmu podzielonej płatności nie stosuje się przepisów dotyczących:

a) odpowiedzialności solidarnej nabywcy z dostawcą towarów z art. 105a ust. 1 u.p.t.u.;

b) sankcji w VAT w postaci dodatkowego zobowiązania podatkowego, o których mowa w art. 112 b ust. 1 pkt 1 , art. 112 b ust. 2 pkt 1 oraz art. $112 c$ u.p.t.u.

Ponadto wprowadzone przepisy przewidują wyłączenie podwyższonej stawki odsetek za zwłokę, o której mowa w art. 56b Ordynacji podatkowej ${ }^{26}$ w przypadku powstania zaległości podatkowej za okres rozliczeniowy, za który podatnik w złożonej deklaracji podatkowej wykazał kwotę podatku naliczonego, której co najmniej 95\% wynika z otrzymanych przez podatnika faktur, które zostały zapłacone z zastosowaniem mechanizmu podzielonej płatności.

Niemniej jednak skorzystanie $\mathrm{z}$ tych zachęt będzie niemożliwe, jeżeli podatnik wiedział, że faktura zapłacona $\mathrm{z}$ zastosowaniem mechanizmu podzielonej płatności związana jest $\mathrm{z}$ nadużyciem prawa, $\mathrm{tj}$.:

1) została wystawiona przez podmiot nieistniejący;

2) stwierdza czynności, które nie zostały dokonane;

3) podaje kwoty niezgodne z rzeczywistością;

4) potwierdza czynności, do których mają zastosowanie przepisy art. 58 i 83 Kodeksu cywilnego.

Ustawodawca wyłącza więc przyznanie korzyści wynikających z mechanizmu podzielonej płatności w przypadku, gdy podatnik miał świadomość co do wskazanych nadużyć. Po stronie organu podatkowego będzie zatem wykazanie nie tylko, że dana sytuacja wskazana w pkt 1-4 miała miejsce, lecz również że podatnik o niej wiedział.

Ustawa przewiduje także obowiązek dla organu podatkowego dokonania zwrotu różnicy podatku od towarów i usług w terminie 25 dni w przypadku, gdy podatnik zawnioskuje o przekazanie tego zwrotu na rachunek VAT. Z jednej strony jest to rozwiązanie niezwykle korzystne, z drugiej jednak należy pamiętać, że podatnik nie będzie mógł swobodnie korzystać

${ }^{26}$ Ustawa z dnia 29 sierpnia 1997 r. Ordynacja podatkowa (tekst jedn. Dz.U. z 2017 r., poz. $201 \mathrm{ze} \mathrm{zm}$.). 
ze środków z tytułu zwrotu (chyba że otrzyma zgodę organu w tym zakresie w formie postanowienia), co może mieć znaczenie zwłaszcza dla podatników dokonujących $\mathrm{w}$ danym okresie rozliczeniowym znacznych inwestycji. W praktyce oznacza to więc, że faktyczny termin zwrotu różnicy podatku wynosi 85 dni ( 25 dni na zwrot na rachunek VAT i 60 dni na wydanie postanowienia na przekazanie środków z rachunku VAT na inny rachunek). W konsekwencji nowelizacja przepisów nie poprawia sytuacji podatników (obecnie podstawowy termin zwrotu wynosi $60 \mathrm{dni}$ ).

Ustawodawca proponuje też zachętę do stosowania mechanizmu podzielonej płatności dla dokonujących dostawy towarów lub usługodawców. W przypadku bowiem, gdy kwota zobowiązania podatkowego z tytułu podatku od towarów i usług zostanie w całości zapłacona z rachunku VAT przed terminem płatności tego podatku, kwota zobowiązania $\mathrm{z}$ tego tytułu będzie mogła podlegać obniżeniu (kwotę obniżenia będzie się wyliczać według wzoru wskazanego w ustawie). Wydaje się jednak, że zachęta ta może nie być adekwatna do strat ponoszonych przez podatników w związku z zachwianiem ich płynności finansowej, o czym mowa dalej.

Wprowadzone przepisy przewidują również, że w przypadku dokonania płatności w ramach mechanizmu podzielonej płatności na rzecz podatnika innego niż dostawca towarów lub usługodawca, podatnik, na rzecz którego dokonano takiej płatności, odpowiada solidarnie z dostawcą lub usługodawcą za niezapłacony przez dostawcę lub usługodawcę podatek wynikający z tej dostawy lub świadczenia usług. Odpowiedzialność ta jest wyłączona w przypadku dokonania przez tego podatnika płatności na rachunek VAT dostawcy towarów lub usługodawcy wskazanego na fakturze bądź podatnika, od którego otrzymano tę płatność, w kwocie odpowiadającej wysokości kwoty otrzymanej na rachunek VAT.

Ustawa przewiduje także możliwość zastosowania omawianego mechanizmu w przypadku zwrotu całości lub części zapłaty w związku z wystawieniem faktury korygującej.

5. KORZYŚCI I ZAGROŻENIA ZWIĄZANE Z MECHANIZMEM PODZIELONEJ PŁATNOŚCI

Wprowadzenie mechanizmu podzielonej płatności łączy się z licznymi korzyściami. Z pewnością przyczyni się do walki z uchylaniem się od opodatkowania w sferze podatku od towarów i usług (co potwierdza chociażby system włoski). W związku $\mathrm{z}$ tą regulacją zabezpieczone zostaną 
interesy Skarbu Państwa w ten sposób, że podatek zapłacony dostawcy lub usługodawcy trafi na wyodrębnione konto VAT, a z niego co do zasady na rachunek organu podatkowego. W znacznym stopniu zostanie więc wyeliminowana praktyka polegająca na otrzymywaniu przez dostawcę lub usługodawcę kwoty brutto i nieodprowadzaniu podatku do zapłaty na rzecz właściwego organu.

Należy jednak uwzględniać, że polskie regulacje przewidują, iż zapłacona kwota podatku od towarów i usług trafia na wyodrębniony rachunek VAT, którego właścicielem jest podatnik. W systemie czeskim i włoskim natomiast płatność VAT dokonywana jest bezpośrednio na rachunek organu podatkowego. W związku z tym polski mechanizm podzielonej płatności nie jest wolny od ryzyka nieuiszczenia kwoty zobowiązania podatkowego przez podatnika. Biorąc wszakże pod uwagę fakt, że z rachunku VAT będą mogły być realizowane ściśle określone operacje finansowe (obejmujące przede wszystkim zapłatę podatku od towarów i usług na rzecz właściwego organu podatkowego), ryzyko w przypadku zaimplementowania omawianego mechanizmu ulega zmniejszeniu w stosunku do obowiązującego modelu poboru podatku.

Nie może uciec z pola widzenia, że zastosowanie się do mechanizmu podzielonej płatności wiąże się z korzyściami dla podatników. Dotyczy to, po stronie nabywców, uniknięcia odpowiedzialności solidarnej nałożenia sankcji oraz podwyższonej stawki odsetek w przypadku uiszczenia płatności za pomocą omawianego mechanizmu. Z kolei po stronie sprzedawców zastosowanie się do tego mechanizmu i dokonanie wcześniejszej płatności podatku na rzecz organu będzie się wiązało z odpowiednim obniżeniem zobowiązania podatkowego. Kolejnym argumentem przemawiającym na korzyść omawianej regulacji jest możliwość otrzymania przyspieszonego zwrotu nadwyżki podatku naliczonego nad należnym, tj. w terminie $25 \mathrm{dni}$ (pod warunkiem złożenia wniosku o przekazanie zwrotu na rachunek VAT), choć podatnik nie będzie mógł swobodnie dysponować zwróconą kwotą.

Niemniej jednak należy zauważyć, że wdrożenie omawianego mechanizmu niesie za sobą pewne zagrożenia. Regulacja ta może bowiem poważnie wpłynąć na płynność finansową przedsiębiorców. Wynika to z faktu, że podatnik będący dostawcą bądź usługodawcą będzie mógł swobodnie dysponować tylko kwotą netto otrzymanej należności. Kwota podatku będzie „zamrożona” na odrębnym rachunku VAT. W praktyce gospodarczej obserwuje się, że podatnicy, w celu realizacji ciążących na nich zobowiązań 
handlowych, potrzebują całej kwoty należności, włączając kwotę podatku od towarów i usług ${ }^{27}$. Płynność finansowa zwłaszcza małych i średnich przedsiębiorstw i tak doznaje uszczerbku, biorąc pod uwagę choćby obowiązujące na rynku wydłużone terminy zapłaty w transakcjach handlowych.

Ponadto przedsiębiorstwa w trosce o zachwianie płynności finansowej mogą zaciągać kredyty i inne zobowiązania i ponosić $\mathrm{z}$ tego tytułu dodatkowe koszty. W praktyce więc, uwzględniając fakt, że mechanizm podzielonej płatności będzie dobrowolny, strony transakcji handlowych mogą zawierać porozumienia, zgodnie z którymi płatność za towary lub usługi będzie dokonywana w formie tradycyjnej.

Z punktu widzenia zachowania płynności finansowej sytuacji przedsiębiorstw nie zmieni co do zasady możliwość otrzymania zwrotu nadwyżki podatku naliczonego nad należnym w przyspieszonym terminie. W przypadku ponoszenia wydatków na znaczne inwestycje i uiszczenia $\mathrm{z}$ tego tytułu podatku naliczonego, podatnik nie będzie mógł swobodnie dysponować otrzymaną kwotą zwrotu (którą uiścił ze środków przeznaczonych na bieżącą działalność). Zwrot w takim przyspieszonym trybie będzie bowiem trafiał na rachunek VAT. Poza tym, jak już zauważono, w przypadku kiedy podatnik chciałby dysponować kwotą zwrotu, termin tego zwrotu wydłuża się do 85 dni.

Warto nadmienić, że wprowadzenie mechanizmu podzielonej płatności wiąże się z poniesieniem znacznych nakładów finansowych. Po pierwsze, banki i SKOK-i poniosły koszty dostosowania systemów bankowych (które to koszty ostatecznie zostały przerzucone na przedsiębiorców). Po drugie, przedsiębiorstwa stanęły przed koniecznością modyfikacji informatycznych systemów księgowych. Po trzecie, wdrożenie mechanizmu podzielonej płatności wiąże się ze zwiększeniem stałych kosztów obsługi księgowej w firmach.

Biorąc pod uwagę powyższe, należy zauważyć, że nieprzypadkowo mechanizm podzielonej płatności nie jest powszechnie stosowany w innych państwach. Z kolei tam, gdzie system ten został zaimplementowany, tj. we Włoszech i Czechach, jest on stosowany w ograniczonym zakresie.

${ }^{27}$ Mechanizm ten dotknie przede wszystkim podatników, którzy wykazują nadwyżkę podatku naliczonego nad należnym, np. dokonując sprzedaży ze stawką $8 \%$, a nabywając towary i usługi według stawki podstawowej. 
Wprowadzenie mechanizmu podzielonej płatności jest z pewnością kolejnym krokiem $\mathrm{w}$ walce $\mathrm{z}$ oszustwami podatkowymi na gruncie podatku od towarów i usług. Wydaje się jednak, że w relacjach pomiędzy podmiotami pozostającymi w stałych relacjach biznesowych instytucja ta, ze względu na ryzyko utraty płynności finansowej, nie będzie na co dzień wykorzystywana. Może ona zyskać popularność w przypadkach, gdy nabywca nie ma pewności co do rzetelności swojego kontrahenta (a tym samym może nastąpić promowanie uczciwych podatników).

Dużą wadą omawianej regulacji jest jej wpływ na płynność finansową dostawców i usługodawców. W szczególności ucierpieć mogą mali przedsiębiorcy, zawierający umowy z dużymi kontrahentami. Ci drudzy mogą odgórnie przyjąć w ramach polityki firmy nakaz podzielonej płatności. W konsekwencji sytuacja finansowa tych pierwszych będzie uzależniona od sposobu działania nabywcy (jak podkreślono powyżej, sytuacji przedsiębiorstw nie zmieni co do zasady możliwość otrzymania zwrotu nadwyżki podatku naliczonego nad należnym w przyspieszonym terminie).

Biorąc pod uwagę fakultatywny charakter mechanizmu podzielonej płatności, można stwierdzić, że nie do końca przyczyni się on, wbrew intencjom ustawodawcy, do zachowania równych zasad konkurencji. W uprzywilejowanej sytuacji znajdą się bowiem ci podatnicy, którzy będą otrzymywać płatności w normalnym, dotychczasowym trybie. Równe zasady konkurencji zostałyby zachowane, gdyby system ten był obligatoryjny (co nie oznacza, że wówczas nie byłby pozbawiony wad).

Warto się także zastanowić, czy wprowadzając omawiany mechanizm, nie należałoby zacząć od jego manualnego wariantu. Z pewnością wiązałby się on z dużo mniejszymi nakładami finansowymi aniżeli system zautomatyzowany. W dalszej perspektywie można byłoby przyjąć ten drugi model, weryfikując jednak na wersji manualnej, czy mechanizm podzielonej płatności sprawdzi się w Polsce.

\section{BiBLIOGRAFIA}

Italy, European Union - Split payment system - request for extension, News IBFD, 22.02.2017, IBFD Tax Research Platform.

La Grutta S., Split-Payment Mechanism for Public Bodies, „International VAT Monitor” 2015 , no. $3 / 4$. 
NIK, Informacja o wynikach kontroli. Przeciwdziałanie wprowadzaniu do obrotu gospodarczego faktur dokumentujących czynności fikcyjne, nr ewid. 24/2016/P/15/011/KBF, Warszawa 2016.

Proposal for a Council Implementing Decision authorising the Italian Republic to apply a special measure derogating from Articles 206 and 226 of Directive 2006/112/EC on the common system of value added tax, Brussel 2017, IBFD Tax Research Platform. Split payment. Raport PwC, 2015, https://www.pwc.pl/pl/pdf/split-payment-raport-pwc. pdf (dostęp: 4.10.2017).

Study on the feasibility of alternative methods for improving and simplifying the collection of $V A T$ through the means of modern technologies and/or financial intermediaries, Executive summary, 20.09.2010, https://ec.europa.eu/taxation_customs/sites/taxation/ files/docs/body/vat-study_summ_en.pdf (dostęp: 4.10.2017).

\section{SPlit PAYMENT MECHANISM - EVALUATION OF THE NEW REgUlation}

Summary. The aim of the article is to evaluate provisions concerning a split payment mechanism. At first, the nature and models of this mechanism were discussed. Then, the regulations applicable in this respect in different countries were presented. What is more, provisions implementing the split payment to Polish VAT were analysed. Finally, the advantages and risks connected with the split payment mechanism were pointed out.

Keywords: split payment mechanism, tax on services and services, tax fraud, sealing of the tax system 